\title{
Productive Performance of Alfalfa (Medicago sativa L.) at Different Age of Resprout in the Spring Season
}

\author{
Álvarez-Vázquez, Perpetuo ${ }^{1}$; Encina-Domínguez, Juan Antonio ${ }^{1 *}$; Ventura-Rios; Joel ${ }^{1}$; Flores-Naveda, Antonio ${ }^{1}$; \\ Hernández-Pérez, Armando ${ }^{1}$; Maldonado-Peralta, Ramiro²
}

\begin{abstract}
${ }^{1}$ Universidad Autónoma Agraria Antonio Narro, Unidad Saltillo. Calzada Antonio Narro 1923, Buenavista, Saltillo, Coahuila, México. ${ }^{2}$ Instituto Tecnológico Superior de Guasave. Tecnológico Nacional de México. La Brecha SN, Ejido Burrioncito, Sinaloa, México.
\end{abstract}

*Corresponding Author: juan.encinad@uaaan.edu. $\mathrm{mx}$

\begin{abstract}
Objective: To determine the growth and productive performance curves, to obtain the optimal cutting moment in alfalfa, depending on the age of resprouting, in the Spring season.

Design/Methodology/Approach: The treatments were cuts at different age of the plant and the variables evaluated: Dry Matter Yield (DMY) Botanical and Morphological composition (BMC), Plant Height (PH), Leaf/Stem Ratio (L/SR), and Intercepted Radiation (IR). The stastical analysis was with the PROC GLM procedure, of the SAS software, and the adjusted curves were obtained with the Curve Expert Professional 2.0 software.

Results: There was an increase in the DMY, leaf, stem, PH, and IR, as the resprouting age advanced, but not, the L/SR which had an inverse behavior. The maximum DMY was obtained (4,768 kg DM ha $\left.{ }^{-1}\right)$ in week seven. There was a greater amount of leaf with average $52 \%$, followed by the stem (36\%), weeds (7\%), detritus (4\%) and inflorescence (1\%). The PH was higher in week seven with $53 \mathrm{~cm}$. Likewise, the highest IR in week tree with $86 \%$. However, the L/SR was higher in week one with 2.4. The IR and L/SR presented the lowest R2 (0.90 and 0.93, respectively). In contrast, DMY and PH presented a positive relationship ( $R^{2}$ of 0.98 and 0.97 , respectively).
\end{abstract}

Study Limitations/Implications: There were no limitations

Findings/Conclusions: The productive performance of Premium variety alfalfa was variable depending on the resprouting age, in which the botanical and morphological characteristics changed, with better characteristics in the fifth week.

Keywords: Medicago sativa L., resprouting age, botanical-morphological composition.

\section{INTRODUCTION}

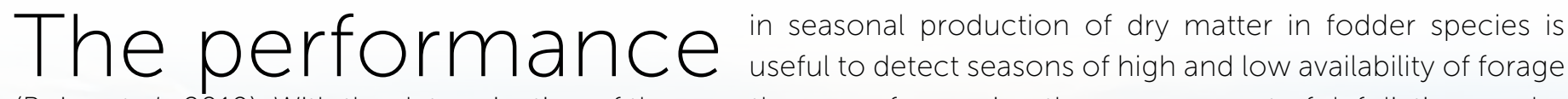
(Rojas et al., 2019). With the determination of the growth curve of a species, the management of defoliation can be established, which will make the production of fodder efficient and reduce the deterioration of meadows (Hernández

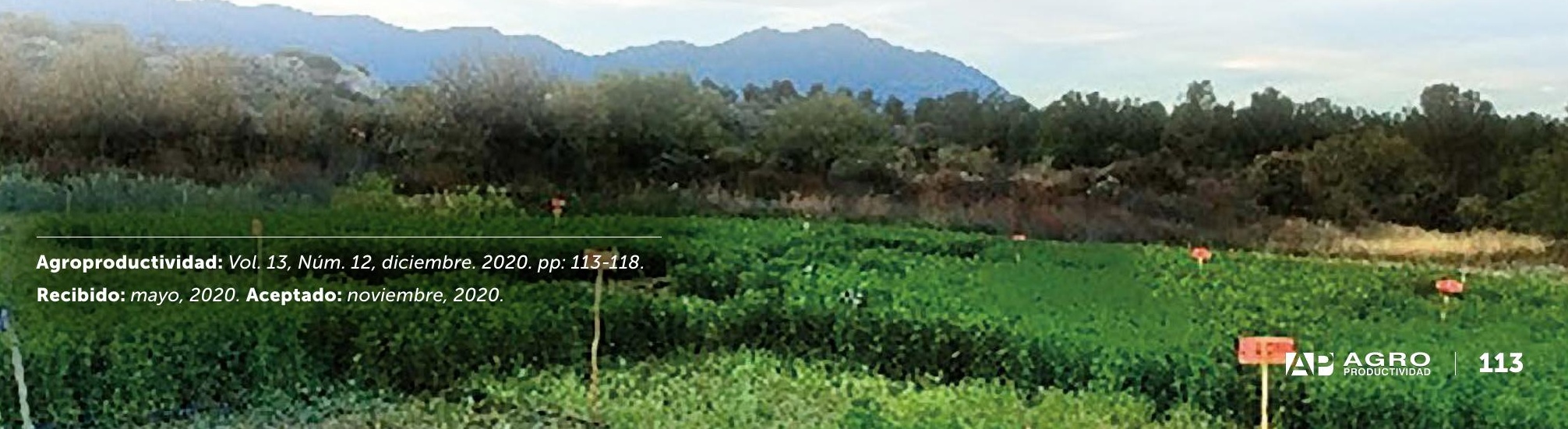


and Martínez, 1997). Likewise, the productivity of a meadow is in function of management, influencing the production of kg DM ha ${ }^{-1}$, and changes in the population, density and size of stems, which determine the rate of appearance, elongation and halflife of the leaf (Rojas et al., 2016). On the other hand, the analysis of a fodder's growth in a specific climate and place is a tool that determines the moment of biomass production of higher quality, considering the morphological and botanical composition, and in addition predicts the yield of leaf, stem, detritus, and inflorescence and thus establishes an adequate crop management (Wilson et al., 2017). Also, the studies consider that the quality of the fodder is related with productive variables such as the specific leaf area and the height of the crop, which at the same time is related with the intercepted radiation. The latter can be used as an indicator for an adequate harvest (Berone, 2016; Da Silva and Nascimento, 2007; Da Silva and Hernández, 2010). Therefore, it is important to determine the optimal moment for cutting, so that a producer can advance or delay its harvest, depending on the needs for fodder. As a result, the objective of this study was to determine growth and productive performance curves in order to obtain the optimal moment of harvesting for alfalfa (Medicago sativa L.) variety Premium, in function of the age of harvest in the Spring season.

\section{MATERIALS AND METHODS}

Study Area: An alfalfa meadow (Medicago sativa L.) was used, Premium variety, in its first year of establishment, in the experimental area "El Bajio" of the Antonio Narro
Agrarian Autonomous University, in Saltillo, Coahuila, Mexico (2523' latitude North and $101^{\circ} 00^{\prime}$ longitude West), at an altitude of $1783 \mathrm{~m}$. The climate is semi-dry temperate, with average temperature of $18{ }^{\circ} \mathrm{C}$ and some days with temperatures below zero ${ }^{\circ} \mathrm{C}$, with mean annual precipitation of $340 \mathrm{~mm}$ (Climate-Data-org, 2010).

Plot Management: The meadow was established on February 4, 2019. The experimental area was divided into 21 plots of $9 \mathrm{~m}^{2}(3 \times 3 \mathrm{~m})$. At the beginning a standardization cut was made (May 4, 2019), at an average height of $5 \mathrm{~cm}$, manually with a sickle. Weekly samples were continued for seven times, randomly selecting three plots and each one was considered a repetition. Irrigation was applied at field capacity every 15 days, when necessary, through an irrigation system by underground drip using a band caliber 6000, buried at $25 \mathrm{~cm}$ of depth, and $60 \mathrm{~cm}$ of separation.

\section{Evaluated and Calculated Variables}

Dry Matter Yield: By repetition, two quadrants of $0.25 \mathrm{~m}^{2}(50 \times 50 \mathrm{~cm})$ were harvested randomly at a height of $5 \mathrm{~cm}$ from the ground. The biomass obtained was deposited in paper bags and dried in a forced air stove Model POM-246F, at a temperature of $55^{\circ} \mathrm{C}$ for $72 \mathrm{~h}$, until constant weight, and the values were expressed in $\mathrm{kg} \mathrm{DM} \mathrm{ha}{ }^{-1} \mathrm{cut}^{-1}$.

Botanical and Morphological Composition: A sub-sample of the harvested fodder was used (approximately 10\%) to estimate the dry matter yield. The sub-sample was separated into leaf, stem, detritus, inflorescence and weeds. The components were dried together with the samples to estimate dry matter. The contribution of the components to the yield in percentage and kg DM ha ${ }^{-1}$ was determined.

Plant Height: Twelve random measurements were taken, by repetition, with a wooden ruler of $100 \mathrm{~cm}$, of $1 \mathrm{~mm}$ precision, and an average value by repetition was obtained.

Leaf:Stem Ratio: It was determined with the leaf and stem values of the botanical and morphological composition, when dividing $\mathrm{kg} \mathrm{DM} \mathrm{ha}^{-1}$ of leaf by the stem.

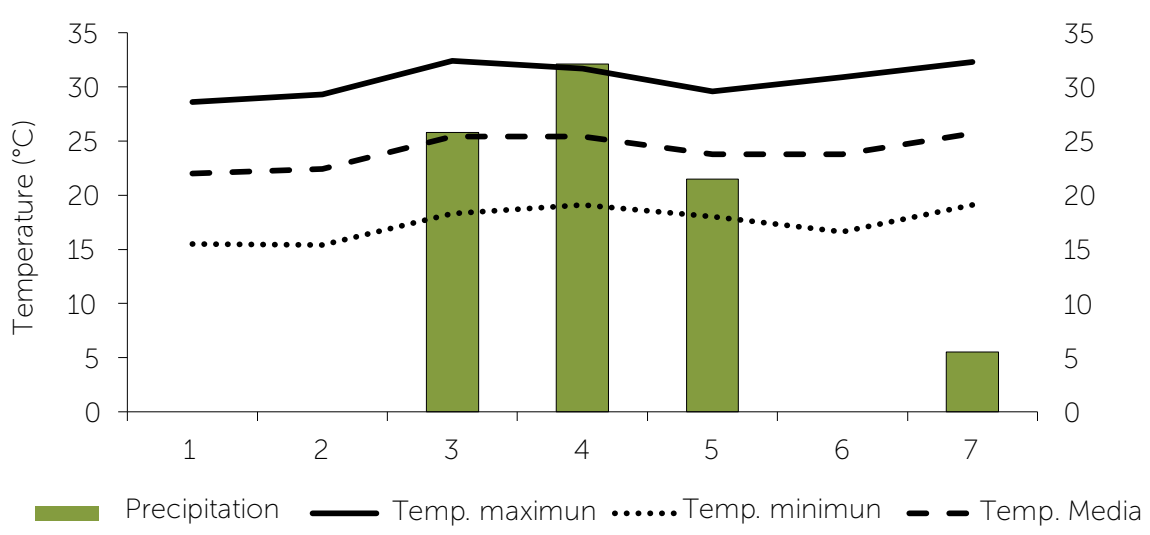

Figure 1. Mean, maximum and minimum temperature, weekly and accumulated precipitation during the study period (February 4 to June 21, 2019). 
Intercepted Radiation: It was calculated from the light data received (readings on the canopy) and negotiated (under the canopy), taken with a quantum sensor of $70 \mathrm{~cm}$ length, model PS-100, Apogee Inst, Utah, USA, between 13:00 and 14:00 h. In order to determine the percentage of light intercepted, the formula used was:

$$
\% L I=((L T-L R) * 100) / L R
$$

where $\% L I=$ Percentage of light intercepted, $L R=$ Light received, and $L T=L i g h t$ transmitted through the canopy.

Statistical Analysis: The statistical analysis was carried out with the PROC GLM procedure, from SAS (2004), for a completely random design with three repetitions. A means comparison was performed using Tukey's test $(p<0.05)$. The adjusted growth curves with their respective models and coefficients were obtained with the Curve Expert Professional 2.0 software (Curve Expert Computer Software. Vers 2.0 N.p. D.d. Web).

\section{RESULTS AND DISCUSSION}

Dry Matter Yield: The weekly increase in dry matter yield, as the plant's age increased, is shown in Figure 2, where a positive trend was observed as the resprouting age increases. The production of dry matter increased during resprouting with $\mathrm{R}^{2}$ of 0.98 , describing a linear curve, because the change in fodder production was constant through time. In this regard, Rojas et al. (2019) show similar trends in red clover (Trifolium pratense L.), with positive trends in growth with $R^{2}=0.98$, adjusting to a linear equation. Likewise, in cereals, the $R^{2}$ found are $>0.93$, but the adjustment is an exponential model (Wilson et al., 2017). The values ranged from $488 \mathrm{~kg}$ DM ha ${ }^{-1}$ in the first week, to $4,768 \mathrm{~kg}$ DM ha ${ }^{-1}$ in week 7 , with an average production of $2,603 \mathrm{~kg} \mathrm{DM} \mathrm{ha}^{-1}$, so they presented differences between weeks of resprouting $(p<0.05)$, showing a positive growth up to week six. For the state of Oaxaca, Montes et al. (2016) reported alfalfa yields at 49 days of 2,794 $\mathrm{kg} \mathrm{DM} \mathrm{ha}^{-1}$, in the same Spring season. In turn, during an evaluation of cutting intervals, Gaytán et al. (2019) obtained yields of 6,844 kg DM ha-1, in a 4-week interval. In this study the values are different, since according to Álvarez et al. (2018), the conditions of climate (Tukey $\mathrm{p}<0.05$ ) and soil are determining factors in the production of fodder.

Botanical and Morphological Composition: The changes in botanical and morphological composition of alfalfa, harvested at different resprouting ages, are presented in Figure 3. From the first week and until week 7, the contribution of the components of dry matter production ( $\mathrm{kg} \mathrm{DM} \mathrm{ha}{ }^{-1}$ ) increased. The leaf was what contributed most with $52 \%$ average, followed by the stem, weeds, detritus and inflorescence, with $36,7,4$ and $1 \%$, respectively. The leaf reached its maximum percentage of contribution (59\%) in week 2 , and it decreased to $41 \%$ in week seven. In the stem, an increase of $21 \%$ was observed in the first week, until $38 \%$ in week seven, with its maximum contribution in week five (41\%). In the detritus and weeds, the values ranged between 0 and $11 \%$ and 2 and 19\%, respectively, without having a clear trend. In turn, the inflorescence emerged in the last three weeks of sampling, which reflects the physiological maturity of the plant. Therefore, it is recommended to harvest alfalfa in the fifth week of resprouting, where an acceptable proportion of leaf is found, compared to the rest of the components and in addition reflected a higher amount of fodder, at the beginning of flowering (Figure 3). However, Mendoza et al. (2010) established that the highest distribution of leaf, regardless of the season of the year, is found in cutting intervals of three to four weeks. For their part, Gaytan et al. (2019) found that alfalfa harvested four weeks after resprouting show the highest leaf productions in meadows one and two years of established, with yields of 5,856 and $3,900 \mathrm{~kg} \mathrm{DM} \mathrm{leaf} \mathrm{ha}^{-1}$.

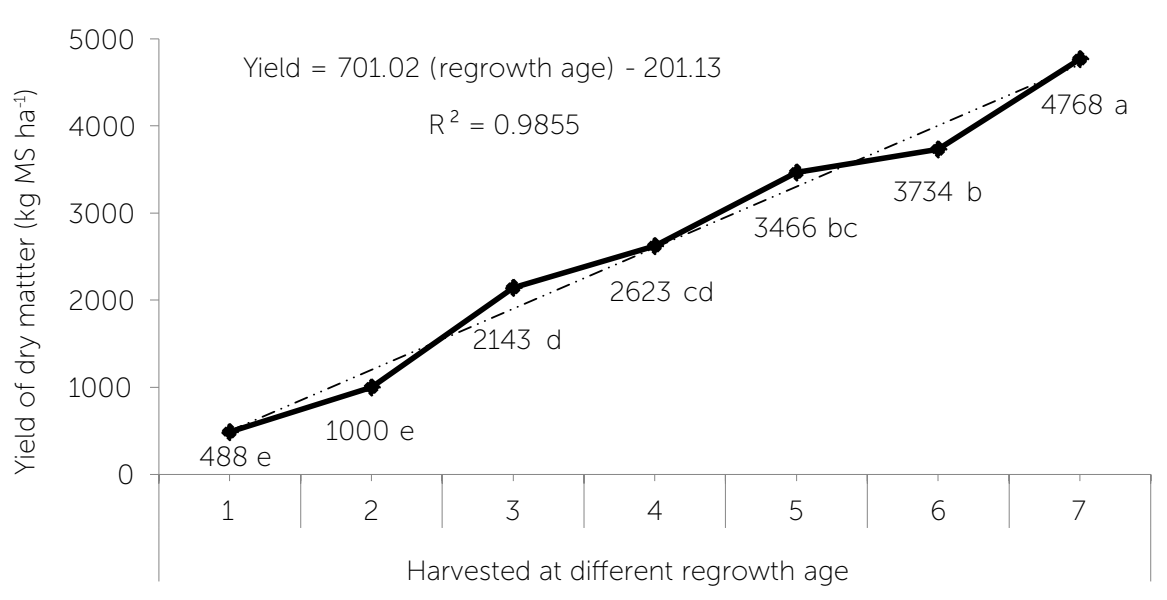

Figure 2. Dry matter yield ( $\mathrm{kg} \mathrm{DM} \mathrm{ha}^{-1}$ ) of alfalfa (Medicago sativa L.), harvested at different resprouting age. Different lowercase letters between cuts indicate statistical differences 

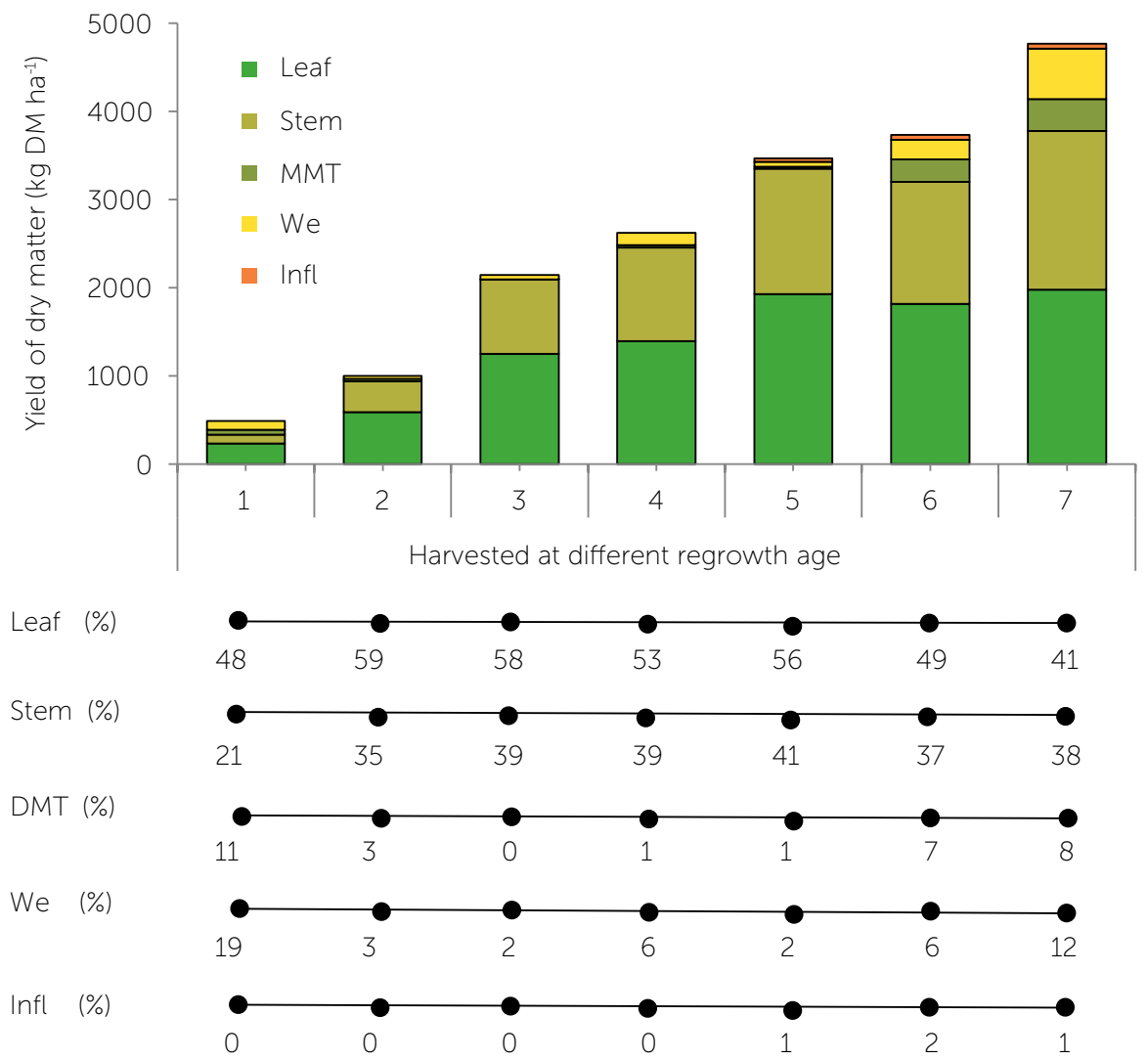

Figure 3. Botanical and Morphological Composition (BMC) of lucerne harvested at different regrowth age. $\mathrm{DMT}=$ Dead material, We $=$ Weed, $\operatorname{Infl}=$ Inflorescence. better to a polynomic model, with $\mathrm{R}^{2}$ of 0.97 . According to Gaytán et al. (2019), the highest values of plant height were obtained in week four, in one-year meadows established with values of $37 \mathrm{~cm}$, and they were higher in a defoliation frequency of three weeks with 28 $\mathrm{cm}$. The data obtained in this study are different from those reported, since under certain experimental and environmental conditions (Figure 1), the variety managed could determine the parameters of growth and yield of alfalfa (Mustafa et al., 2010).

Leaf:Stem Ratio: The trend that alfalfa presented during seven weeks of resprouting is shown in Figure 5 . As the age of resprouting increases, the leaf:stem ratio decreased. The values ranged from 2.4 in week one to 1.4 in week four. This value was maintained from week four to six, ending in a minimum value in week seven of $1.1(p<0.05)$. The value of $\mathrm{R}^{2}$ is acceptable with 0.93 . The values higher than one show that the leaf component was always higher in proportion than the stem, which is why according to Rojas et al. (2019) it should be taken as reference for the quality of fodder. For their part, Zaragoza et al. (2009) report average values in alfalfa of 1.1, in week one and 0.5 in week eight, similar trend to the one found in this study. Likewise, Rojas et al. (2019) found values of

0.94 in the fourth week of resprouting in five varieties of alfalfa. However, in meadows of one and three years of established, when comparing frequencies of defoliation of four and five weeks, they report values of 2.8 and 3.4, respectively (Gaytán et al., 2019). However, in other studies the lowest leaf:stem ratio has been obtained in the resprouting ages where the highest dry matter yield is presented (Rivas et al., 2005), which is why it is important to evaluate the weight and height of the stems in relation to the leaf. Concerning this, Sun et al. (2011) reported a greater height in correspondence to a lower
Figure 4. Plant height (cm) of alfalfa (Medicago sativa L.) harvested at different resprouting age. Different lowercase letters between cuts indicate statistical differences (Tukey $p<0.05)$
Plant height $=$

+19.685 (regrowth eges) -4.1217 -1.6743 (regrowth ages) $2+19.685($ regr
$R^{2}=0.9795$

\begin{tabular}{|c|c|c|c|c|}
\hline 3 & 4 & 5 & 6 & 7 \\
\hline
\end{tabular}

Harvested at different regrowth age 


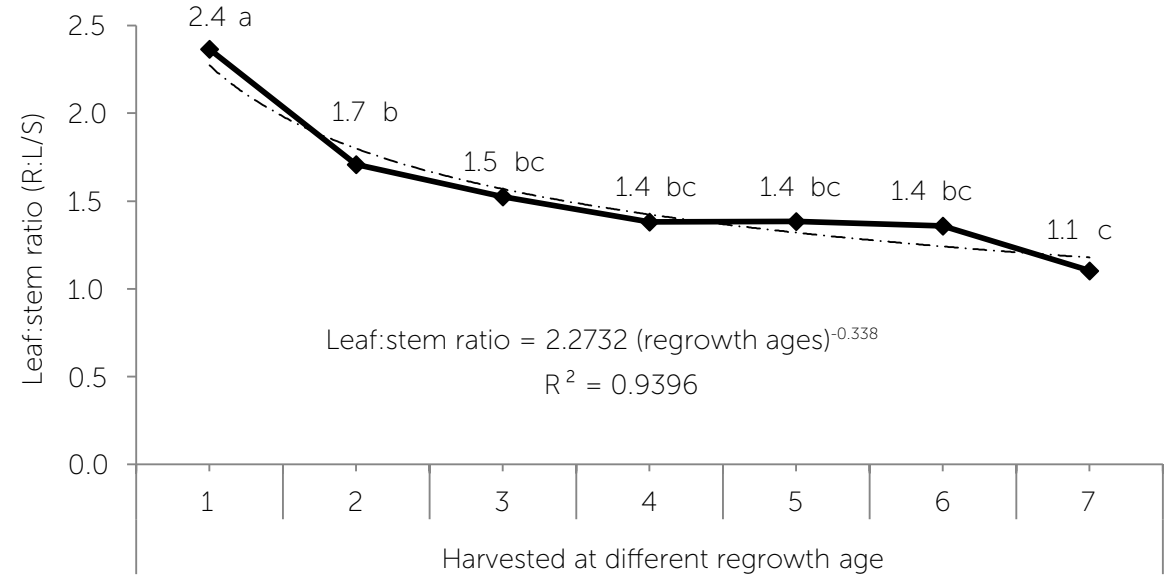

Figure 5. Leaf:stem ratio (R:H/T), alfalfa (Medicago sativa L.), harvested at different age of resprouting. Different lowercase letters between cuts indicate statistical differences (Tukey $\mathrm{p}<0.05)$

amount of leaf, decreasing the leaf:stem ratio when approaching the flowering stage.

Intercepted Radiation: The behavior that the variable of intercepted radiation followed is shown in Figure 6, where $\mathrm{R}^{2}$ of 0.90 was obtained, positive correlation as the age of the plant was higher. In general, a progressive increase in the percentage of light intercepted was found, from week one to week three $(p<0.05)$, and continuing with constant values until week seven $(p>0.05)$. The maximum percentage of light intercepted was reached in week three and four with $86 \%$ and the lowest in week one with $37 \%(p<0.05)$. In the Spring season, Rojas et al. (2016) reported a maximum value of intercepted radiation of $93 \%$ in the Jupiter variety, which in both studies is below the $95 \%$ value, percentage found for an optimal harvest (Montagner et al., 2012), as long as the plant density is competitive. In this regard, at differences between plants of $10,15,20,25$ and $30 \mathrm{~cm}$, in Spring it is possible to obtain $95 \%$ of intercepted light, while in Summer and Winter they are only reached at 10 and $15 \mathrm{~cm}$ of distance between plants (Mattera et al., 2013). Despite this, Baldissera et al. (2014) mention that the lower the separation between plants, the higher the radiation of intercepted light, fodder yield, and leaf area index. However, in the Summer season, $95 \%$ of the intercepted light was found in the Jupiter variety (Rojas et al., 2016), which is why it is advisable to study the Premium variety, evaluated in this study, in the rest of the seasons of the year, since differences have been reported between times of the year (Mendoza et al., 2010; Rojas et al., 2012).

\section{CONCLUSIONS}

The performance of the growth curve of alfalfa (Medicago sativa L.), Premium variety, was variable in function of the resprouting age of the species. As the date of harvest increased, the morphological and botanical characteristics changed, obtaining a balance between quality and quantity, between the third and fourth week of evaluation, with a higher percentage of leaf, compared to the stem in the Spring season. It is recommended to continue evaluating this species in a longer time in other seasons of the year.

\section{REFERENCES}

Álvarez, V. P., Hernández, G. A., Mendoza, P. S-I., Rojas, G. A-R, Wilson, G. C-Y., Alejos, D. la F. J-I. (2018). Producción de diez variedades de alfalfa (Medicago sativa L.) a cuatro años de establecidas. Agrociencia, 52(6): 841-851

Baldissera, T. C., Frak, E., Carvalho, P. C. F. and Louarn, G. (2014). Plant development controls leaf area expansion in alfalfa plants competing for light. Ann. Bot. 113:145-157

Berone, G. D. (2016). Leaf expansion and leaf turnover of perennial C4 grasses growing at moderately low temperatures. Revista de la Facultad de Ciencias Agrarias. Universidad Nacional de Cuyo. Mendoza. Argentina. 48(2): 69-82.

Climate-Data-org. (2010). https://es.climate-data.org/america-delnorte/mexico/coahuila-de-zaragoza/saltillo-4988/

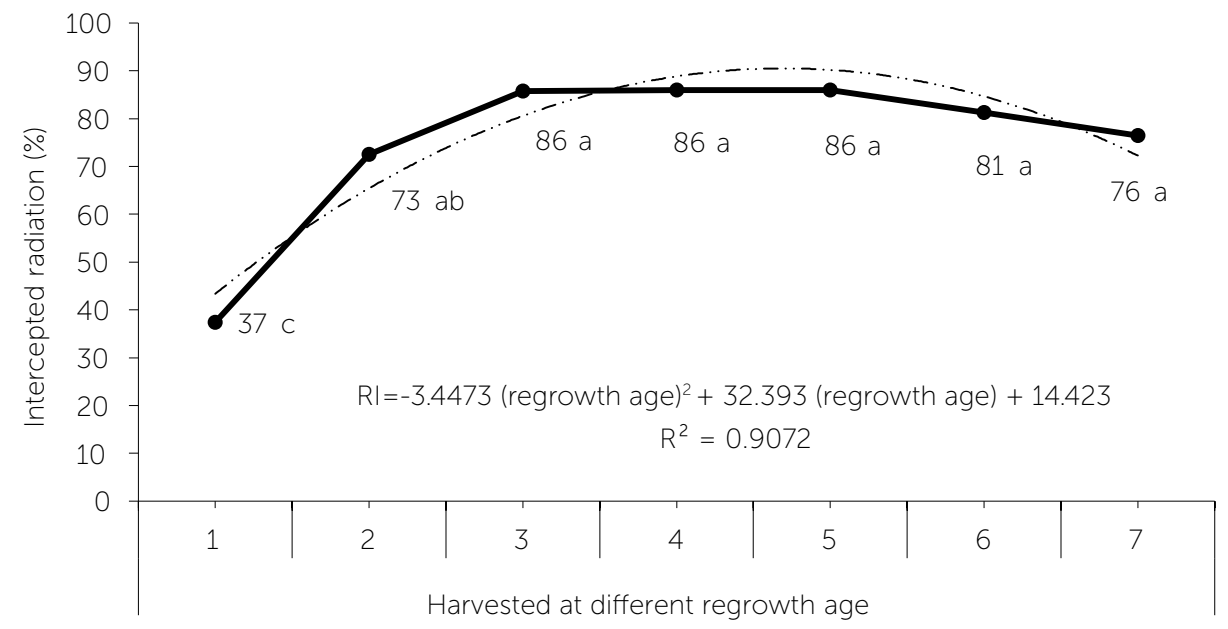

Figure 6. Intercepted Radiation (RI = \%) of alfalfa (Medicago sativa L.), harvested at different age of resprouting. Different lowercase letters between cuts indicate statistical differences (Tukey $\mathrm{p}<0.05)$ 
Da Silva, S. C. y Hernández, G. A. (2010). Manejo del pastoreo en praderas tropicales. En: Los forrajes y su impacto en el trópico. UNACH. Chiapas, México.

Da Silva, S. C., y Do Nascimento, J. D. (2007). Avanços na pesquisa com plantas forrageiras tropicais em pastagens: características morfofisiológicas e manejo do pastejo. Rev. Bras. Zootec. 36: 122-38.

Gaytán, V. J-A., Castro, R. R., Villegas, A. Y., Aguilar, B. G., Solís, O. M-M., Carrillo, R. J-C., Negrete, S. L-O. (2019). Rendimiento de alfalfa (Medicago sativa L.) a diferentes edades de la pradera y frecuencias de defoliación. Revista mexicana de ciencias pecuarias, 10(2): 353-366.

Hernández, G. A., y Martínez, H. P. A. (1997). Utilización de pasturas tropicales: En Torres H.G. y Díaz R.P. (Eds). Producción de ovinos en zonas tropicales. Fundación Producce-INIFAP. 8-24 pp.

Mattera, J., Romero, L. A., Cuatrin, A. L., Cornaglia, P. S. and Grimoldi, A. A. (2013). Yield components, light interception and radiation use efficiency of lucerne (Medicago sativa L.) in response to row spacing. Eur. J. Agron; 45:87-95.

Mendoza, P. S-I., Hernández, G. A., Pérez, P. J., Quero, C. A-R., Escalante, E. J. A-S., Zaragoza, R. J-L. y Ramírez, R. O. (2010). Respuesta productiva de la alfalfa a diferentes frecuencias de corte. Revista Mexicana de Ciencias Pecuarias; 1:287-296

Montagner, D. B., Nascimento Do Jr., Vilela, H. H., B. M. Sousa, de L. V. P. B. Euclides, S. C. Da Silva, and M. N. Carloto. (2012). Tillering dynamics in pastures of guinea grass subjected to grazing severities under intermittent stocking. Rev. Bras. Zootec. 41: 544-549.

Montes, F. J., Castro, R. R., Aguilar, B. G., Sandoval, T. S. y Solís, O. M. M. (2016). Acumulación estacional de biomasa área de alfalfa Var. Oaxaca criolla (Medicago sativa L.). Revista Mexicana de Ciencias Pecuarias; 7(4):539-552

Mustafa, O-T, y Ilknur A. (2010). Nutritional Contents and yield performances of Lucerne (Medicago sativa L.) cultivars in southern black sea seashores. J Anim Vet Adv; 9 (15):2067-2073.

Rivas, J. M-A., López, C.C., Hernández, G. A., Pérez, P. J. (2005). Efecto de tres regímenes de cosecha en el comportamiento productivo de cinco variedades comerciales de alfalfa (Medicago sativa L.). Téc Pecu Méx; 43(1):79-92.

Rojas, G. A. R., Hernández, G. A., Joaquín, C. S., Maldonado, P. M. A., Mendoza, P. S. I., Álvarez, V. P. y Joaquín, T. B. M. (2016). Comportamiento productivo de cinco variedades de alfalfa. Revista Mexicana de Ciencias Agrícolas; 7(8): 1855-1866.

Rojas, G. A-R., Mendoza, P. SI., De Lira, C. AL., Álvarez, V.P., Maldonado, P.M-A., González, C. P., Pro M.A., Joaquin, C.S., Luna, G. M. (2019). Rendimiento de trébol rojo (Trifolium pratense L.) a diferente edad de cosecha. Agro productividad; 12 (8):11-15.

Rojas, G. A. R., Hernández, G. A., Joaquín, C. S., Mendoza, P. S. I., Guerrero, R. J. D., Zaragoza, R. J. L. (2012) Comportamiento productivo y rendimiento de forraje de cinco variedades de alfalfa. 2da Reunión Internacional conjunta de manejo de pastizales y producción animal. Zacatecas, México 336-340 p.

Sun, Y., Yang, Q., Kang, J., Guo, W., Zhang, T., Li, Y. (2011). Yield evaluation of seventeen lucerne cultivars in the Beijing area of China. J Agric Sci; 3(4):215-223.

Wilson, G. CY., Hernández, G. A., Ortega C. ME, López, C. C., Bárcena, G. R., Zaragoza, R. JL., Aranda, O. G. (2017). Análisis del crecimiento de tres líneas de cebada para producción de forraje, en el valle de México. Revista de la Facultad de Ciencias Agrarias; 49(2): 79-92.

Zaragoza, E. J., Hernández, G. A., Pérez, P. J., Herrera, H. J. G., Osnaya, G. F., Martínez, H. P. A., González, M. S. S. y Quero, C. A. L. (2009). Análisis de crecimiento estacional de una pradera asociada de alfalfa-pasto ovillo. Técnica Pecuaria en México, 47(2), 173-188

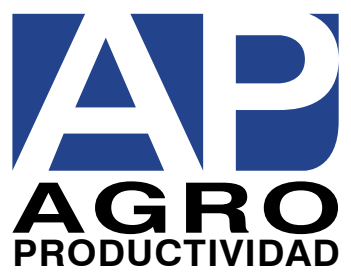

